\title{
Strategic Social Action Plan for MERCOSUR: Income transfer programs in the context of a neoliberal offensive ${ }^{1}$
}

\author{
Rosilaine Coradini Guilherme \\ Universidade Federal do Pampa, Curso de Serviço Social, São \\ Borja, RS, Brazil (UNIPAMPA)
}

\section{Carlos Nelson dos Reis}

Pontifícia Universidade Católica do Rio Grande do Sul, Escola de Humanidades, Programa de Pós-Graduação em Serviço Social, Porto Alegre, RS, Brazil (PUCRS)

Strategic Social Action Plan for MERCOSUR: Income transfer programs in the context of a neoliberal offensive

Abstract: This article analyzes the Strategic Social Action Plan for the Common Market of the South (MERCOSUR), based on its relationship with the Millennium Development Goals, which means articulating the reflection to the context of the neoliberal offensive in Latin America. Epistemologically the study is based on the dialectical-critical method, involving exploratory research, with a survey of documentary and bibliographic sources. This research revealed that the focus of the social agenda is the establishment of an exit door or the sustained emancipation of families, by means of individual training, based on the theory of human capital and neoliberal ideology. The scope of the study presupposes presenting the contents of the historic processes and the theoretical concepts that permeate the proposals contained in the Strategic Plan, to stimulate the debate about the issue.

Keywords: Mercosur. Social Action. Income Transfer.

Received on 06.15.2017. Approved on 09.05.2017. Reviewed on 11.17.2017.

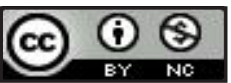

(C) The Author(s). 2018 Open Access This article is distributed under the terms of the Creative Commons Attribution-NonCommercial 4.0 International License (http://creativecommons.org/ licenses/by-nc/4.0/), which permits use, distribution, and reproduction in any medium, since it's for non-commercial purposes, and provided you give appropriate credit to the original author(s) and the source, provide a link to the Creative Commons license, and indicate if changes were made. 


\section{Introduction}

The geo-economic characteristic of the Common Market of the South (MERCOSUR) - based on an interregional commercial agreement whose objectives include integration, constitution of new markets and competitiveness in international markets - proved to be insufficient to reduce the social impacts of neoliberal economic policies, materialized in the process of productive re-structuring and structural adjustment. A report by the Economic Commission for Latin America (CEPAL) about the region, reproduced by the European Commission, affirmed that "the crisis of 1999-2002 provoked a dramatic drop in employment rates and an increase of poverty and social exclusion" (COMISSÃO EUROPEIA, 2007, p. 13). This conjuncture developed after a decade of (in)voluntary adhesion by Latin American countries to the first generation reforms formulated in 1989 in the Washington Consensus, with the objective of assisting Latin America to overcome its slow growth through structural adjustment.

Nevertheless, instead of accelerating growth, structural adjustments were made that affected social rights - which in Brazil, for example, had finally become guaranteed by the constitution only in 1988 - and that have been targets of neoliberal policy reforms since the 1990s. It must be remembered that in Latin America the implementation of conditional income transfer programs was contemporary to the first-generation reforms suggested in 1989 in the Washington Consensus. The previously mentioned structural adjustments also coincided with the institutionalization of MERCOSUR, through the Treaty of Asuncion, signed in 1991. Although the conception of economic development with social justice is explicit in the introduction to the Treaty, ${ }^{2}$ the economic block only began to expand its social dimensions in the decade of 2000. "A marker for the debate about the social dimensions is, in the first place, recognizing that social protection, institutionalities and MERCOSUR are intimately linked to three inter-related themes that permeate this triad, that is, regional integration, rights and citizenship" (NOGUEIRA, 2008, p. 156).

In this context, in 2000 the MERCOSUL countries signed the United Nations (UN) Millennium Declaration, which called for a reduction of extreme poverty by 2015 to half the levels of 1990. A distinct concern arose among wealthy nations for establishing a development model that would include middle and low-income countries, and focused on reducing extreme poverty and promoting social cohesion. At a national level, the conditional income transfer program - represented by the Family Grant Program that has been implemented since 2003 is the main government strategy for confronting extreme poverty. ${ }^{3}$ In fact, the debate about the conditional income transfer programs "deepened in the 1990s, and in the early twenty-first century constituted what can be considered the main strategy in the current focus of the Social Assistance Policy of the Brazil Social Protection System." (SILVA; YAZBEK; GIOVANNI, 2004, p. 33).

This corresponds to the prevalence of focused social policies and on making the family nucleus and or community and civil society responsible in the field of social protection, to the degree that the state would only intervene when an individual does not have the means to provide for their own subsistence or have it provided by the family. To go deeper into this line of reflection, this study is epistemologically based on the dialecticalcritical method, due to a theoretical option and the specificity of the study, which involves explaining the contradictions inherent to the capitalist mode of production through the problematization of the historic contexts analyzed. To do so, it focuses on the years 1990-2016, and the Latin American continent, emphasizing the countries of the Common Market of the South (MERCOSUR). It is a quanti-qualitative study of an exploratory nature, in which the survey of data is based on documental sources and a Brazilian and international bibliography.

This article is organized as follows: in addition to this introduction, the second section conducts a reflection, to express the theoretical concepts that support the United Nations Millennium Development goals, articulating the debate to the structural adjustment process imposed on Latin American countries, which was based on the first and second generation reforms. The third section presents an analysis of the recent economic growth strategy, including redistribution, described in the Strategic Social Action Plan (MERCOSUL). Finally, some considerations are made to synthesize the reflections, highlighted by the contents of the historic processes and the theoretical concepts that permeate the propositions of the Strategic Social Action Plan. Therefore, the importance of this study for the field of knowledge of social service and related areas is justified by the set of issues problematized.

\section{United Nations Millennium Development goals and the Structural Adjustment Reforms in Latin America}

United Nations documents express a growing consensus about the importance of inclusionary economic growth with redistribution, as well as the need for international accords for the elimination of poverty and 
hunger at a global level, focused on low and middle income level countries. The effort was exemplified by the realization of the United Nations Millennium Assembly held in New York City in 2000, with the presence of 147 heads of state. At this time, UN Secretary General Kofi Annan, presented the We the Peoples the Role of the United Nations in the $21^{\text {st }}$ Century (SACHS, 2005). The document "became the basis for the important Millennium Declaration (...) which established a series of quantifiable goals and a determined period to reduce poverty, diseases and want." (SACHS, 2005, p. 249). These goals were based on eight dimensions: to eradicate poverty and hunger; universalize primary education; promote equality among the sexes and independence of women; reduce infant mortality; improve maternal health; fight HIV/AIDS, malaria and other diseases; guarantee environmental sustainability; and establish a global partnership for development.

In practice, based on 1990 data, it sought to reduce poverty rates by half by 2015, and to eliminate it by 2025. In relation to the latter goal, it is important to associate it to the vision of the UN Assistant for the Millennium goals who classified development assistance, by rich to poor countries, as an insignificant effort-less than $1 \%$ of the income of the wealthy world - understanding that "doing less than this is to declare to a large portion of the world: 'you are worthless'. Therefore, we should not be surprised if in later years the wealthy collect the storms of this impious seeding." (SACHS, 2005, p. 331-332). This declaration allowed elucidating the narrow limit of the global partnership for development, although it was among the millennium development goals. It mainly reveals a supposed commotion or altruism of the wealthy countries that were summoned to make an insignificant effort, through assistance to the development of poor countries, (re)establishing the economic and moral superiority of the civilized nations on territories composed of (neo)colonized countries.

It is fitting to relate this convergence to the economic interdependence led by the financial market, the impacts of which, as well as the market instabilities created, regardless of their origin, represent a systemic risk. In order to contain them the author of the first generation reforms - John Williamson (2004a) - presented new recommendations - announced as the second generation of reforms, which would be crisis proof. Operationally, the first generation reforms formulated in 1989 in the Washington Consensus, materialized in structural adjustments such as: state budget discipline, especially in relation to investments in social policies, triggering restrictive reforms in social protection systems; destatization of public institutions through privatization, outsourcing and commodification of the provision of basic social rights such as healthcare and social security; liberalization of financial flows and the expansion of the external market, representing, together with the privatizations, broad flexibilization of the labor market and social rights.

This context is coherent to the so-called structural adjustment proposed by the central capitalist countries and executed by multilateral financial agencies such as the World Bank and the International Monetary Fund, which determine the principle of fiscal austerity to the low and middle-income countries. "Here is the meaning of structural adjustment programs against development, imposed by the IMF and the World Bank on the indebted countries." (IAMAMOTO, 2008, p. 118). Although Williamson disagrees, some authors, particularly Marxists, use the expression as a synonym for the neoliberal ideological agenda. In his opinion "the reason was obvious: it is a gift from God to all the opponents who did not accept the reform who longed for socialism or for industrialization via import substitution or a state in which they could perform a principal role" (WILLIAMSON, 2004b, p. 285). In his interpretation - contradictorily - economic crises are the result of the incomplete execution of first generation reforms by the Latin American countries, above all those that encompass the social protection systems and the labor market. For this reason, the second generation of recommendations associates institutional reforms - independence of the central bank and judicial reform - with a social agenda such as income distribution and expansion of opportunities for the poor.

It should be highlighted that the second generation reforms included: income distribution; improved education aimed at the development of human capital; agrarian reform modeled after the Brazilian program because it offered help to rural workers to purchase land from the latifundium, respecting property rights; and the expansion of micro-credit with the reduction of market rate interest rates (WILLIAMSON, 2004a). It is understood that the way that this new social agenda was conceived, in addition to preserving the market economies, would promote access by the poor to resources that would allow them to "construct their path out of poverty". This emphasis is associated to the theory of human capital, whose principles involve the idea that "by investing in themselves, people can expand the range of choice available to them. This is one of the ways by which free men can increase their well-being" (SCHULTZ, 1973, p. 3). This theory - based on (neo)liberal principles - considered itself innovative, because it added investment in the human factor to those elements understood to be needed for the reproduction of capitalist sociability. The argument is that this factor - in addition to strengthening the abilities of individuals so that they would have greater effectiveness in the productive processes - higher rates of private profit - would increase economic growth. "To the degree that the expenses for increasing these capacities also increase the value of productivity of human effort (labor) they produce a positive rate of return." (SCHULTZ, 1973, p. 41). 
In this sense, in 2011, the instrument aligned with the Millennium Goals was passed, entitled the Strategic Social Action Plan of MERCOSUR. Its central focus was the eradication of hunger, poverty and fighting social inequalities, mainly through food and nutritional security measures, as well as distributive policies such as conditional monetary income transfer programs and complementary actions, with a focus on families in situations of extreme poverty. In Latin America, the implementation of the conditional income transfer programs is contemporaneous to the adhesion by the nation states to the first generation of reforms suggested in 1989 under the Washington Consensus. In the conception of the Economic Commission for Latin America (CEPAL) (2009), these initiatives were central to social policies for fighting poverty in seventeen countries of the region, encompassing $17 \%$ of the population.

These are programs that do not involve contributions from beneficiaries "that seek to simultaneously increase consumption by families by offering monetary transfers - and thus reduce poverty in the short term and strengthen the human capital of its members to break the intergenerational reproduction of poverty" (CEPAL, 2009, p. 29). The fact is that this logic involves a reorientation of the social protection systems, that is, "the public investment in universal social security policies, considered inefficient, expensive and inhibitive of economic growth, is aimed at the conditional income transfer programs, focused on the extreme poor, which are considered to be innovative and highly diffused." (SILVA, 2014, p. 108).

In fact, these programs seek to guarantee minimal living conditions for people whose personal and family income is insufficient for their subsistence. They are social policies of an assistance oriented and non-contributive nature focused on poverty and indigence, conceded in monetary and non-monetary forms, through means testing and compliance with certain conditions. In conformity with this line of reflection, the next section will analyze the Strategic Social Action Plan in the realm of MERCOSUR, to reveal its particularities, based on its relationship with the Millennium Development Goals, which means articulating the reflection to the context of the deepening of the neoliberal offensive in Latin America. The scope of the study presupposes explaining the contents of historic processes and the theoretical concepts that permeate the proposals contained in the Strategic Social Action Plan, to stimulate debate about the issue.

\section{The Strategic Social Action Plan of MERCOSUR}

The Strategic Social Action Plan 4 appears in the document entitled Foci, Guidelines and Priority Objectives of the Strategic Social Action Plan of MERCOSUR, approved at the Asuncion Summit in 2011, with the presence of ministers and secretaries responsible for social policies. Specifically, the Plan is composed of ten lines of focus, twenty-six guidelines and various priority objectives - and represents the first joint initiative to implement social projects on a regional level. By order of priority, the ten lines of focus are: eradicating hunger, poverty and fighting social inequalities; guaranteeing human rights, humanitarian assistance and racial, ethnic and gender equality; universalizing public health and education and eradicating illiteracy; valuing and promoting cultural diversity; guaranteeing productive inclusion; assuring access to decent labor and social security rights; promoting environmental sustainability; assuring social dialog; and establishing mechanisms for regional cooperation to implement and finance social policies.

In 2012, MERCOSUL published a informational brochure with the complete contents of the Plan and the decree that sanctioned its enactment - MERCOSUL/CMC/DEC. $\mathrm{N}^{\circ} 12 / 11$. It was understood that the new instrument would be "essential to articulating and developing specific, integral and inter-sectoral actions, which consolidate the social dimension of MERCOSUL" (MERCOSUL, 2012, p. 38). The publication mentions changes in the objectives of MERCOSUR, because its first decade was predominated by relations based on the principle of "commodification until the crisis of the millennium provoked a decrease in intra-regional commercial relations, dispelling perspectives for growth and increasing levels of poverty and unemployment" (MERCOSUL, 2012, p. 10). As a result, the block agreed that the importance and "understanding of the social dimension, in the process of regional integration supposes conceiving non-compensatory social policies that would support economic growth, but assumes that all public policies will conform to a strategy for human development." (MERCOSUL, 2012, p. 14).

In theoretical terms, this reconceptualization was supported - as mentioned in the presentation of the booklet - by Amarthya Sen's concept of development as liberty. For Sen, who is associated to neoliberal theory, social opportunities "(in the form of education and health services) facilitate economic participation. Economic facilities, (in the form of opportunities for participation in commerce and production) can help generate individual abundance, as well as public resources for social services." (SEN, 2000, p. 25-26). For a better analysis, it is possible to identify that this theoretical support postulates that for people to have autonomy, they need other aspects, beyond income, such as health, education, housing and safety. Therefore, here is the 
fundamental problem, because by calling for autonomy through income as the means, it winds up obscuring the end which is to strengthen the market.

In the details of the Strategic Social Action Plan - a document published as an addendum to the Decree - to eradicate hunger and poverty - a priority line of focus - a few objectives are established such as guaranteeing access to social assistance services for families in situations of social vulnerability and risk, and to develop monetary income transfer programs and complementary actions. The Plan does not refer to pre-school education, and has generic objectives such as guaranteeing equal opportunities for access, permanence and conclusion with quality, in an opportune time, to children and youth to educational systems. In Latin America and the Caribbean, the population 25 and older "has increased its level of average schooling: from 2.9 years in 1950 to 7.9 years in 2010. In the European Union, there has also been a strong increase in this indicator: from 5.2 years to 10.6 years in the same period." (CEPAL, 2012, p. 46, our translation). It is important to highlight that this data indicates that the levels of educational disparities between the countries in the European Union (EU) and MERCOSUR, have remained nearly the same as 60 years ago.

In contrast, to expand higher education the Strategic Social Action Plan emphasizes distance education as a means to attain social inclusion and democratization. Thus, like the goal to eradicate illiteracy, it is articulated to social programs, especially those for blacks, women, people with disabilities, people older than 50 and the indigenous. These proposals express historic inequalities caused by exploitive relations and or oppression based on gender, race, ethnicity and generation. Although the official discourse to the expansion of higher education through distance education affirms the democratization of education - presenting Brazil as an example - what in fact has occurred is its alignment to a market logic - in detriment to the social right to free, quality public education. "The common point of the expansion of distance courses is the leadership of private for-profit businesses - which have in this educational modality an opportunity to expand their rates of accumulation." (IAMAMOTO, 2008, p. 442).

As in education, the gender perspective is emphasized in the line of focus concerning access to decent work and to social security rights, because it includes the following objectives: salary equality between men and women; labor rights for domestic workers, mainly in border regions; and valorization of non-remunerated domestic labor. It should be highlighted that in 2012 the unemployment rates in most countries of Latin America and the Caribbean was below 10\% - lower than rates in the European Union, which in some cases were above $20 \%$, as in Spain, Ireland, Italy and Greece, which "are those affected by the fiscal adjustments, the sovereign debt crisis and by the restrictive adjustment programs" (CEPAL, 2012, p. 29, our translation). In relation to demographic changes, while the population of the European Union "is aging, which will reduce its relevance in coming years, Latin America and the Caribbean is younger, encompassing higher birth rates", this means that "in the European Union this indicator will reach $47 \%$ by 2050 [...]. In Latin America and the Caribbean, this indicator will increase to 30 until 2050." (CEPAL, 2012, p. 21, our translation).

Among the member countries of MERCOSUL, this data is institutionally treated as factors that produce consequences - in terms of budget deficits - in the field of social security, composing the list of justifications for restrictive reforms to the social protection systems, denominated as austerity measures. For example, the levels of spending for social protection - social security and assistance - as a percentage of GNP in Latin America and the European Union reveal that while "in the latter the expenses represented 5.1\% of GNP in 2008-2009, in the EU the average is nearly five times greater $-22.9 \%$ of GNP. This difference remained relatively stable in the past decade."

The fact is that the explanatory categories introjected by MERCOSUR such as human capital, productive inclusion from the perspective of entrepreneurship, social cohesion and integration and inclusionary growth, obscure the theoretical status of the social question. For this reason, it makes the moral justification for the social provisions in the realm of the state - to include income security - focusing on the extremely poor. (CEPAL, 2012, p. 44, our translation). The healthcare line in the Strategic Social Action Plan highlights the objective of promoting its universalization, as well as articulating regional agreements that guarantee access to 
healthcare in border regions. Another line of the Plan highlights the perspective of productive inclusion, as well as micro-companies, and encourages other initiatives such as family farming and a solidarity economy.

Another specificity identified in the Strategic Social Action Plan is the idea of promoting access to land, agrarian reform and sustainable rural development, with attention to the perspective of gender. In general, it is noted that the proposals from MERCOSUR give priority to eradicating hunger, poverty and fighting social inequalities, mainly through food and nutritional security programs, as well as the perspective of productive inclusion and distributive policies such as conditional monetary income transfer programs, and complementary actions focused on families in situations of extreme poverty. Nevertheless, these proposals should be compared with the recommendations of the social agenda proposed by John Williamson (2004a), and known as second generation reforms: income distribution; improvement in the field of education seeking the development of human capital; agrarian reform similar to Brazilian programs, which help rural workers purchase lands from the latifundia, while respecting property rights; and the expansion of micro-credit with reduction of market interest rates.

The fundamental question to be problematized is that these proposals - as seen - are compatible to those of the Strategic Social Action Plan. For this reason the document lacks clarity about aspects such as the concept of agrarian reform that MERCOSUR supports. In addition, since the first decade of 2000, MERCOSUR adopted a concept of economic growth with social justice, which according to the official discourse means privileging social investment in human capital and social cohesion, through the expansion of social policies focused on fighting extreme poverty, with a highlight on conditional income transfer programs. In addition to the reference to Amarthya Sen, the Strategic Social Action Plan also presents theoretical influences of Jeffrey Sachs (2005) and Stiglitz (2002). The later, for example, presumes that successful economies make a compatible use of markets and the role of government is to steer sustainable development by focusing on expanding opportunities and individual capacities through education, healthcare and income security. This eclecticism - in the scope of this study - is associated to the neodevelopmentalist or neo-Keynesian strategy of the decade of 2000 which influenced the conception of development in Latin American countries. "It is not an economic theory, but a national development strategy based mainly on Keynesian macroeconomics and on the economic theory of development." (BRESSER-PEREIRA, 2010, p. 42).

Nevertheless, as in the developmentalist period, this new model collides with the world's highest rates of inequality, as well as expressive rates of poverty and indigence. "Two central ideas are at the base of this ideology: a) that which maintains that the confrontation of neoliberalism is conducted with economic growth mediated by state intervention; b) that which maintains that economic growth leads inexorably to social development" (MOTA, 2012, p. 34). Here is the moral justification for offering services that privilege the extreme poor - as in conditional income transfer programs - associated to the idea that the relative improvement in social indicators contributes to create a market attractive to foreign capital and, therefore, promotes sustained economic growth. "Sustained economic growth requires that poor countries increase their exports to rich countries and, in this way, obtain the foreign currency needed to import capital goods from these countries." (SACHS, 2005, p. 323). This perspective of growth is addressed by Williamson, Stiglitz and Sachs, ${ }^{5}$ whose principles include the moral responsibility of the rich countries to reduce extreme poverty on a global level.

Contradictorily, the goal "is to do away with extreme poverty, not with all poverty, and even less, to make global incomes equal or end the distance between rich and poor. This may wind up happening, but to do so, the poor will have to get rich thanks to their own effort" (SACHS, 2005, p. 332). The authors also refer to the lack of opportunities or human capital, among the poor, so that they can create options to escape poverty, which can cause stagnation or a decline in economic growth. "The fundamental problem for the poorest countries is that poverty itself can be a trap. When poverty is very extreme the poor do not have the capacity - on their own to escape from the predicament." (SACHS, 2005, p. 85). The fact is that the explanatory categories introjected by MERCOSUR such as human capital, productive inclusion from the perspective of entrepreneurship, social cohesion and integration and inclusionary growth, obscure the theoretical status of the social question. For this reason, it makes the moral justification for the social provisions in the realm of the state - to include income security - focusing on the extremely poor.

It must be clear that the reality of the social question - materialized in social inequalities - involves the exploitation of the labor force by capital in the sphere of production and consumption. Therefore, to treat it as a synonym for social exclusion, for example, hides that "it is characteristic of capitalist society to uproot workers, exclude to include in another way, according to its logic." (IAMAMOTO, 2008, p. 166). The fundamental point is that the depoliticized interpretation of the social question - which is the object of the work of the social worker - represents the advance of neo-conservativism or of post-modern theories that "exalt the particularism and the differences, as substantive - and not complementary - to the contradictions and inequalities of classes, in a broad ideological undertaking that invades scientific knowledge." (IAMAMOTO, 2008, p. 470). This critical approach sustains this study because it associates the processes 
of productive restructuring initiated in the 1970s to the structural adjustments in development under the preponderance of the financial market that directly affect the world of labor and all dimensions of life to the degree to which it produces a banalization of humans.

\section{Final considerations}

It is thus evident that, a global consensus is developing over the need for the elimination of poverty and hunger with a focus on the poorest countries such as those in Latin America, in the name of global governability of the capitalist mode of production. The preponderance of the international agencies (the World Bank and the International Monetary Fund) in the control of the global economy, especially on the low and middle income countries such as those of Latin America, is directly related to the control of government spending, with an emphasis on spending for social policies, to guarantee regularity in the payment of the foreign debt in favor of the central countries. The social implications of this economic and technological dependence are materialized in the expansion of income inequality and wealth on the continent, which is considered one of the most expressive in the world.

In fact, contradictorily, international agencies, at the same time as they propose structural adjustments, in the line of austerity, incorporate a discourse of fighting poverty by means of sustained growth. This implicitly expresses - given that in the official global discourse about fighting poverty this concern is not mentioned - the fear of the so-called systemic risk, which is based on the concern that problems in an emerging market can affect the economies of the advanced capitalist countries. In Latin America, the strategy that conjugates economic growth with fighting poverty, through focused social policies - represented in the conditional income transfer programs - without questioning the market economies, is known as neo-developmentalism.

MERCOSUR's Strategic Social Action Plan, were contradictorily presented in relation to the UN Millennium Goals, and to the so-called second-generation structural adjustments of the decade of 2000, under the discourse of inclusionary economic growth. This is clearly a social agenda whose focus involves establishing an exit door or the sustained emancipation of individuals and families, by means of training individuals - as supported by the theory of human capital and neoliberal ideology. Given this trend, it is necessary to deeply analyze the historic processes that shape the direction of poverty and of social protection in Latin America, to make clear their theoretical, political and economic constructs, which are conditioned by determinations internal and external to the continent.

\section{References}

BRESSER-PEREIRA, L. C. Do antigo ao novo desenvolvimentismo na América Latina. São Paulo: EESP/FGV, 2010. Disponível em: $<$ http://bibliotecadigital.fgv.br/dspace/handle/10438/7726>. Acesso em: 24 out. 2014.

COMISSÃO ECONÔMICA PARA A AMÉRICA LATINA E CARIBE. Panorama Social de América Latina. [S.1.]: CEPAL, 2009. Disponível em: <https://www.cepal.org/es/publicaciones/1232-panorama-social-de-america-latina-2009>. Acesso em: 21 out. 2014.

. La Unión Europea y América Latina y El Caribe: inversiones para el crecimiento, la inclusión social y la sostenibilidad ambiental. [S.1.]: ONU; CEPAL, 2012. Disponível em: <http://repositorio.cepal.org/bitstream/handle/11362/3083/ S1200748_es.pdf?sequence=1>. Acesso em: 30 nov. 2014.

COMISSÃO EUROPEIA. Mercosul: Documento de Estratégia Regional 2007-2013 [E/2007/1640]. 2 ago. 2007. Disponível em: $<$ http://eeas.europa.eu/archives/docs/mercosur/rsp/07_13_pt.pdf>. Acesso em: 20 nov. 2014.

GUILHERME, R. C. Renda Mínima de Inserção e Transferência Condicionada de Renda: as (a) simetrias entre União Europeia e MERCOSUL. 2016. 249 f. Tese (Doutorado) - Pontifícia Universidade Católica do Rio Grande do Sul, Porto Alegre, 2016. Disponível em: <http://repositorio.pucrs.br/dspace/handle/10923/8378>. Acesso em: 06 out. 2017.

IAMAMOTO, M. V. Serviço Social em tempo de capital fetiche: capital financeiro, trabalho e questão social. São Paulo: Cortez, 2008. MERCOSUL. Plano Estratégico de Ação Social do MERCOSUL. [MERCOSUR/CMC/DEC. No 12/11]. Assunção: Instituto Social do MERCOSUL, 2012. Disponível em: <http://www.mercosur.int/innovaportal/v/6582/9/innova.front/plano-estrategico-de-ac\%C3\%A3osocial-peas>. Acesso: 11 mar. 2015.

. Tratado para la Constitución de un Mercado Comun entre la República Argentina, la República Federativa del Brasil, la República del Paraguay y la República Oriental del Uruguay. 1991. Disponível em: <http://www.mercosur.int/innovaportal/file/719/1/ CMC_1991_TRATADO_ES_Asuncion.pdf $>$. Acesso em: 29 nov. 2014.

MOTA, A. E. Redução da pobreza e o aumento da desigualdade: um desafio teórico-político ao Serviço Social brasileiro. In: (Org.). Desenvolvimentismo e Construção de Hegemonia: crescimento econômico e reprodução da desigualdade. São Paulo: Cortez, 2012. p. 29-45. 
NOGUEIRA, V. M. R. Direitos e cidadania nos processos de integração regional: o caso Mercosul. In: BOSCHETTI, I. (Org.). Política social no capitalismo: tendências contemporâneas. São Paulo: Cortez, 2008. p. 149-173.

SACHS, J. O Fim da Pobreza: como acabar com a miséria mundial nos próximos 20 anos. São Paulo: Companhia das Letras, 2005. SCHULTZ, T. W. O Capital Humano. Investimento em Educação e Pesquisa. Rio de Janeiro: Zahar, 1973.

SEN, A. K. Desenvolvimento como liberdade. São Paulo: Companhia das Letras, 2000.

SILVA; M. O. S. e. Caracterização e Problematização dos Programas de Transferência de Renda Condicionada (PTRC) na América Latina e Caribe. In (Coord.). Programas de Transferência de Renda na América Latina e Caribe São Paulo: Cortez, 2014. p. $85-232$

.; YAZBEK, M. C.; GIOVANNI, G. di. A Politica Social Brasileira no Século XXI: a prevalência dos programas de transferência de renda. São Paulo: Cortez, 2004.

STIGLITZ, J. E. A Globalização e seus maleficios. São Paulo: Futura, 2002.

WILLIAMSON, J. Uma agenda de trabalho para retomar o crescimento e as reformas. In: .; KUCZYNSKI, P.-P. (Org.). Depois do Consenso de Washington: retomando o crescimento e a reforma na América Latina. São Paulo: Saraiva, 2004a. p. 1-17. . Nossa Agenda e o Consenso de Washington. In: .; KUCZYNSKI, P.-P. (Org.). Depois do Consenso de Washington:

retomando o crescimento e a reforma na América Latina. São Paulo: Saraiva, 2004b. p. 283-291.

\section{Notes}

1 The reflections presented are the byproducts of a doctoral thesis entitled "Renda Mínima de Inserção e Transferência Condicionada de Renda: as (a) simetrias entre União Europeia e MERCOSUL”, defended at PPGSS/PUCRS, in March 2016 (GUILHERME, 2016).

2 "Considering that the expansion of the current dimensions of the national markets, through integration, is a fundamental condition for accelerating their economic development processes with social justice" (MERCOSUL, 1991).

3 It is important to highlight that the program mentioned is a policy that covers the complete territory of Brazil, although it is focused on families living in poverty and extreme poverty, which in early 2016 corresponded to the following intervals, respectively: per capita family income of R\$ 0,00 - R \$77,00; and per capita family income of $\mathrm{R} \$ 77,01-\mathrm{R} \$ 154,00$.

4 MERCOSUL/CMC/DEC. $\mathrm{N}^{\circ} 12 / 11$.

5 U.S. economist Jeffrey Sachs is a special assistant to the UN secretary general for the Millennium Development Goals.

\section{Rosilaine Coradini Guilherme}

rosilaineguilherme@yahoo.com.br

Doctor in Social Work from the Pontific Catholic University of Rio Grande do Sul

(PUCRS)

Adjunct Professor of Social Work in the Federal University of the Pampa (UNIPAMPA)

\section{UNIPAMPA}

São Borja Campus

Rua Ver. Alberto Benevenuto, 3200

São Borja - Rio Grande do Sul - Brasil

CEP: $97.670-000$

\section{Carlos Nelson dos Reis}

cnelson@pucrs.br

Doctor in Political Economy from the State University of Campinas (UNICAMP)

Senior Professor and Researcher in the Graduate Program in Social Work at the Pontific Catholic University at Rio Grande do Sul (PUCRS)

\section{PUCRS}

Av. Ipiranga, 6681 - Partenon.

Porto Alegre - Rio Grande do Sul - Brasil

CEP: $90.619-900$ 